\title{
Metal Levels in Blood of Three Species of Shorebirds during Stopover on Delaware Bay Reflect Levels in Their Food, Horseshoe Crab Eggs
}

\author{
Joanna Burger ${ }^{1,2, *}$ (D), Nellie Tsipoura ${ }^{3}$ and Michael Gochfeld ${ }^{2,4}$ \\ 1 Division of Life Sciences, Rutgers University, 604 Allison Road, Piscataway, NJ 08854, USA \\ 2 Environmental and Occupational Health Sciences Institute, Piscataway, NJ 08854, USA; \\ mg930@eohsi.rutgers.edu \\ 3 New Jersey Audubon, 11 Hardscrabble Rd, Bernardsville, NJ 07924, USA; nellie.tsipoura@njaudubon.org \\ 4 Rutgers Robert Wood Johnson Medical School and School of Public Health, Piscataway, NJ 08854, USA \\ * Correspondence: burger@biology.rutgers.edu; Tel.: +1-848-445-9536
}

Academic Editor: Jose L. Domingo

Received: 31 July 2017; Accepted: 18 August 2017; Published: 28 August 2017

\begin{abstract}
Understanding the relationship between metal level in predators and their prey is an important issue, and is usually difficult to determine because animals eat a variety of organisms. However, shorebirds that stop over during spring migration along Delaware Bay (New Jersey) stay for only 2-3 weeks, and eat mainly horseshoe crab (Limulus polyphemus) eggs. In this paper, we examine the relationship between metal levels in horseshoe crab eggs, and blood and feather levels of metals in red knot (Calidris canutus rufa; $n=30$ ), sanderling (Calidris alba; $n=20$ ) and semipalmated sandpiper (Calidris pusilla; $n=38$ ) from Delaware Bay. There is a rich literature on metal levels in feathers. For all three species, the levels of arsenic, cadmium, chromium, lead and mercury in blood were highly correlated with the levels of metals in the eggs of horseshoe crab (17 pooled samples). This indicates that the levels in the blood of these shorebirds quickly reflect levels in their prey (horseshoe crab eggs), while metals in the feathers were not correlated with the levels in eggs. Semipalmated sandpipers had the lowest levels of arsenic in blood and the highest levels of arsenic in feathers, compared to the other species. At Delaware Bay, semipalmated sandpipers have a diet higher in marsh invertebrates than the other species, which may account for the differences. The levels of cadmium and chromium in blood were significantly higher in knots than other species; knots only ate horseshoe crab eggs. For all of the metals except arsenic, the ratio of levels in blood/feathers was similar among species. For arsenic, the ratio of levels in blood/feathers were significantly lower in semipalmated sandpipers than in the other species, by an order of magnitude.
\end{abstract}

Keywords: arsenic; cadmium; chromium; lead; mercury; shorebirds; red knot; sanderling; sempalmated sandpiper; blood; feathers; horseshoe crab eggs; Limulus polyphemus

\section{Introduction}

Government agencies, conservationists, and the public are interested in levels of heavy metals in wildlife that could prove detrimental to the organisms themselves, or to those that eat them. Heavy metals in biota can also be used to indicate information about the levels in the foods they eat. Coastal birds are often used as bioindicators of contamination because they live in a variety of habitats, occupy different trophic levels, and are exposed to a range of chemicals [1-3]. Further, levels are often higher in coastal areas because of the runoff from rivers [4,5], as well as atmospheric deposition [6,7]. Metals can be sequestered in bottom sediments of bays and estuaries, to be released by storms or strong tides. 
Shorebirds are one of the groups of birds that are mainly coastal; most shorebird species use marine habitats at some time in their life cycle [8]. Many shorebirds migrate long distances from their Arctic breeding grounds to their wintering grounds in South America [9-11], stopping to refuel along the Atlantic coast [12]. Over the last 30 years, many species of shorebirds have declined sharply [13-15]. In the 1990s, about $20 \%$ of the world's shorebirds were listed as species of special concern [16], and now Andres et al. [17] estimate that $61 \%$ of American shorebird populations have declined in the last 30 years. For some species, such as semipalmated sandpipers (Calidris pusilla), data indicate that population declines are mainly occurring in the Atlantic flyway and in the eastern Arctic breeding region [18]. These declines have partly been attributed to difficulty foraging during migration, especially on Delaware Bay [19]. Shorebirds are particularly vulnerable, because many breed in harsh Arctic conditions with a very short breeding season, migrate over long distances, and stop over to refuel at a very small number of coastal bays and estuaries. Thousands stop at the same time and place, making them vulnerable to predation, variable food supplies, intense competition, and human disturbance [20].

During a two to three week stop-over period at Delaware Bay, several species of shorebirds stop to refuel, mainly on the eggs of horseshoe crabs (Limulus polyphemus) [10,21,22]. Delaware Bay supports the largest concentration of northbound shorebirds on the East Coast [23], as well as the largest spawning concentration of horseshoe crabs [24]. Amplexing pairs of horseshoe crabs spawn in the sand at high tide, depositing their eggs in nests that are too deep for the birds to access [25-27]. When the crabs are abundant, newly arriving females dig up the nests of previous spawning females while they deposit their own eggs, releasing the earlier eggs to the surf, making them available to foraging shorebirds $[10,11,28]$. The shorebirds concentrate at the high tide line where the eggs can form dense mats, although they also forage on the intertidal habitat [29]. Decreases in the populations of horseshoe crabs (overharvested for eel and conch bait, Kraemer and Michels [30]) have resulted in decreased egg availability, which in turn has resulted in declines in the number of shorebirds on Delaware Bay $[10,11,31,32]$.

One of the shorebirds that depends upon the eggs of horseshoe crabs during the stopover at Delaware Bay each spring is the red knot (Calidris canutus rufa), which is currently listed as threatened [32,33]. During the spring stopover at Delaware Bay, the red knots and other shorebirds nearly double their weight in order to successfully fly, non-stop, the 6500-km journey to their Arctic breeding grounds [34,35]. With increasing urbanization and industrialization along our coasts, species that forage almost exclusively along the coasts are also exposed to increasing levels of contaminants [36-38]. Thus, shorebirds are exposed to whatever contaminants are in the horseshoe crab eggs, and they eat thousands while in the Bay [22,39].

Red knots and semipalmated sandpipers spend a great deal of time along Delaware Bay foraging on the eggs of horseshoe crabs each May, and although sanderling (Calidris alba) also forage by the thousands along the Bay, they also spend more time foraging along the Atlantic coast beaches (where very few horseshoe crabs spawn) than the other species. Heavy metal concentrations in the blood of knots and semipalmated sandpipers are correlated with the levels of arsenic, cadmium, chromium, lead, and mercury in horseshoe crab eggs [3]. In this paper, we tested the hypothesis that metal levels in the blood of sanderling were also correlated with those in the eggs of horseshoe crabs, and whether the relationships would be similar to the other two species. We were also interested in whether there was the same ratio of metal levels in blood and feathers for all three species.

\section{Materials and Methods}

Our overall protocol was to collect eggs of horseshoe crabs and to collect blood from shorebirds [37,38] from Delaware Bay, under appropriate permits (Figure 1). Eggs were collected from recently laid horseshoe crab nests on spawning beaches in 2012 [39]. Eggs were collected from recently laid clutches, placed in plastic bags, and frozen for later analysis [39]. We pooled eggs from several nests, and analyzed 17 pooled samples. Shorebirds were captured by cannon net. Blood was 
collected from shorebirds in 2011 and 2012, and placed in vials for later analysis at the Environmental and Occupational Health Sciences Institute of Rutgers University. We collected approximately $10 \mu \mathrm{L}$ of blood in 75-uL heparinized capillary tubes. Tubes were placed in labeled non-additive glass Vacutainers to prevent breakage, placed upright on ice, and frozen the same day for later analysis [38]. Blood was collected 4 days after arrival to give the birds time enough to begin restoring weight lost during migration. Blood levels did not vary among years, and the data were pooled. We pulled about 25 breast feathers/shorebird, and stored them in plastic envelopes [3]. Blood and feather samples were not pooled across birds. Individual results were obtained for 30 red knots, 20 sanderlings, and 38 semipalmated sandpipers. All methods were approved by the Rutgers University IACUC (92-036), and conform to guidelines provided by the Ornithological Council (www.nmnh.si.edu/BIRDNET/GuideToUse). These guidelines have been formulated with consideration of animal welfare and research needs.

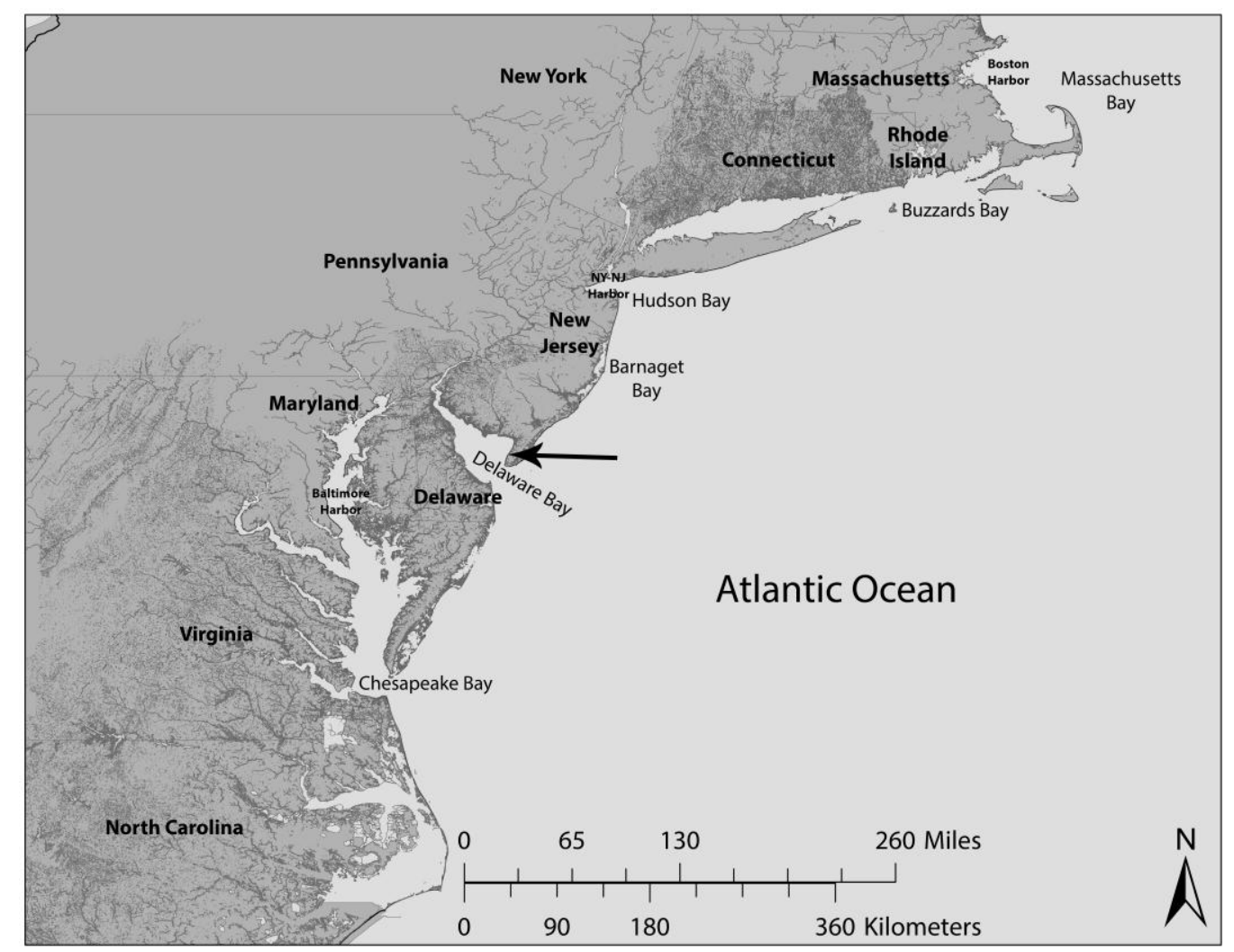

Figure 1. Map showing location of collection of blood of shorebirds and the eggs of horseshoe crabs (see arrow) along Delaware Bay.

Horseshoe crab eggs and avian blood samples were kept frozen until they were transferred to the Elemental Analysis Laboratory of the Environmental and Occupational Health Sciences Institute at Rutgers University. Total mercury was analyzed by cold vapor atomic absorption spectrophotometry, of which about $85-90 \%$ is assumed to be methylmercury [40]. Other metals were analyzed by flameless, graphite furnace atomic absorption. Instrument detection limits were $0.02 \mathrm{ppb}$ for arsenic and cadmium, $0.08 \mathrm{ppb}$ for chromium, $0.15 \mathrm{ppb}$ for lead, and $0.2 \mathrm{ppb}$ for mercury. All specimens were analyzed in batches with known standards, calibration standards, and spiked specimens. Blanks, standard calibration curves, and spiked matrix specimens were used to monitor assay performance for all batches. All concentrations are expressed in $\mathrm{ppb}(\mathrm{ng} / \mathrm{g})$, wet weight for total metal. Recoveries ranged from $87 \%$ to $101 \%$. Batches with recoveries of less than $85 \%$ were reanalyzed. The coefficient of variation on replicate, spiked samples ranged up to $10 \%$. 
We used non-parametric procedures (Kruskal Wallis test, PROC NPAR1WAY [41]) to determine species-related differences in heavy metal levels, and Kendall tau correlations for determining relationships between horseshoe crab egg levels and shorebird blood levels. We used these non-parametric tests because they are more conservative and are best fitted for small datasets.

\section{Results}

There were significant interspecies differences in the arsenic levels in both blood and feathers (Table 1). Semipalmated sandpipers had the lowest levels of arsenic in their blood, but the highest in their feathers. There were significant interspecific differences in the levels of cadmium in blood (but not feathers); red knots had the highest levels of cadmium compared to the other species. Levels of lead in blood, and mercury in feathers, almost reached interspecific significance, and might have with larger sample sizes (Table 1). The ratio of metals in blood/feathers is of interest because it might indicate that levels in either blood or feathers might be useful as a bioindicator if the ratios were similar among species. However, the ratios differed significantly for arsenic and chromium because the levels in blood differed significantly (Table 1).

Table 1. Levels of heavy metals (mean $\pm \mathrm{SE}, \mathrm{ppb}$ ) in shorebirds collected at Delaware Bay, New Jersey, for blood, feathers, and the ratio of blood/feathers.

\begin{tabular}{|c|c|c|c|c|c|}
\hline & Arsenic & Cadmium & Chromium & Lead & Mercury \\
\hline \multicolumn{6}{|l|}{ Red Knot } \\
\hline Blood $(n=30)$ & $1036 \pm 188$ & $2.9 \pm 0.7$ & $484 \pm 62$ & $90 \pm 12$ & $16 \pm 3.1$ \\
\hline Feather $(n=30)$ & $446 \pm 42$ & $17 \pm 2.4$ & $578 \pm 83$ & $484 \pm 67$ & $576 \pm 105$ \\
\hline Ratio & 2.32 & 0.17 & 0.84 & 0.19 & 0.03 \\
\hline \multicolumn{6}{|l|}{ Sanderling } \\
\hline Blood $(n=20)$ & $1288 \pm 193$ & $2 \pm 0.7$ & $122 \pm 21$ & $87 \pm 14$ & $25 \pm 5.3$ \\
\hline Feather $(n=20)$ & $311 \pm 64$ & $10.5 \pm 2.6$ & $463 \pm 63$ & $367 \pm 52$ & $730 \pm 109$ \\
\hline Ratio & 4.14 & 0.19 & 0.26 & 0.24 & 0.03 \\
\hline \multicolumn{6}{|c|}{ Semipalmated sandpiper } \\
\hline Blood $(n=38)$ & $381 \pm 45$ & $1.8 \pm 0.5$ & $268 \pm 52$ & $59.8 \pm 11$ & $12.7 \pm 3.3$ \\
\hline Feather $(n=30)$ & $842 \pm 101$ & $14.2 \pm 2.7$ & $524 \pm 64$ & $411 \pm 46$ & $428 \pm 58$ \\
\hline Ratio & 0.45 & 0.13 & 0.51 & 0.15 & 0.03 \\
\hline \multicolumn{6}{|c|}{ Interspecific Differences $\left(X^{2}\right)$} \\
\hline Blood & $31.9(<0.0001)$ & $6.7(0.04)$ & $27.9(<0.0001)$ & $5.0(0.08)$ & 3.0 (NS) \\
\hline Feathers & $25.4(<0.0001)$ & 2.9 (NS) & 0.7 (NS) & 0.8 (NS) & $5.1(0.08)$ \\
\hline Ratio & $37.9(<0.0001)$ & $1.4(\mathrm{NS})$ & $13.8(0.001)$ & 3.4 (NS) & 0.09 (NS) \\
\hline
\end{tabular}

For all three species, the mean metal levels in the blood were positively correlated with the mean levels of metals in the eggs of horseshoe crabs, their primary prey at Delaware Bay in the spring (Figure 2). For all three species, the Kendall tau was $1(p<0.01)$ as they were completely aligned. Thus, the hypothesis that the metal levels in the blood of sanderling reflected those of crab eggs, and were similar to those of knots and semipalmated sandpipers was supported. The mean levels of cadmium and arsenic in blood of shorebirds were slightly below levels in horseshoe crab eggs, and arsenic was especially lower for semipalmated sandpipers (Figure 2). 


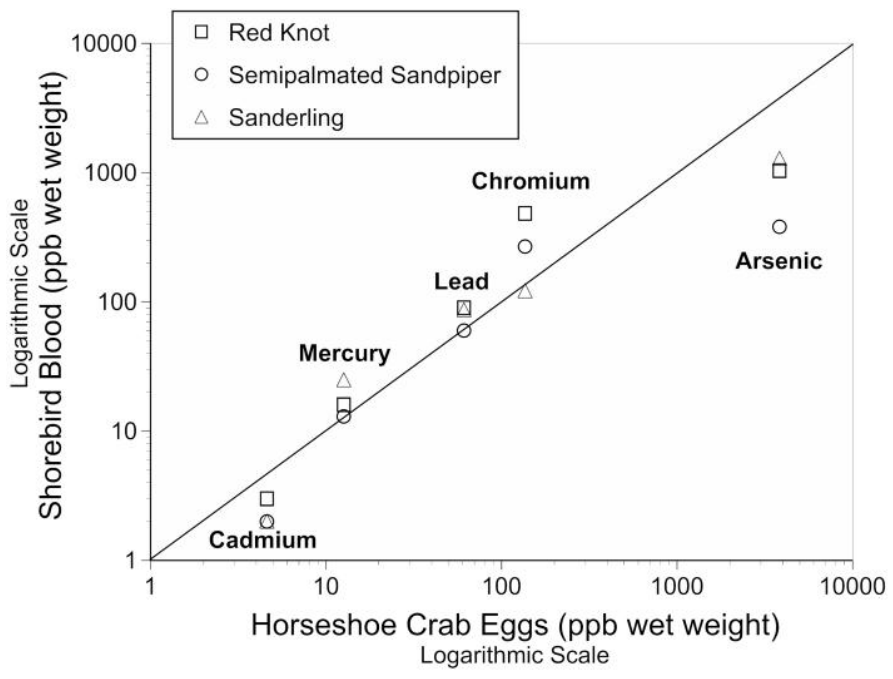

Figure 2. Relationship of mean levels of arsenic, cadmium, chromium, lead and mercury in the blood of three species of shorebirds and the mean level in eggs of horseshoe crabs, their primary prey while on migratory stopover in May at Delaware Bay, New Jersey. (See Table 1).

\section{Discussion}

\subsection{Relationship between Metals in Prey and in Shorebird Blood}

The levels of heavy metals in the blood of all three species were positively correlated with the levels in horseshoe crab eggs, their primary food while they are in Delaware Bay. Although the levels in their prey (horseshoe crab eggs) were slightly lower for some metals, they were the same order of magnitude. These data indicate that the blood quickly reflects local prey levels [3,5]. While many studies assume that heavy metal levels in blood reflect local food levels [42,43], this is usually difficult to show because most birds eat many different prey items. In contrast, in Delaware Bay, the shorebirds primarily eat horseshoe crab eggs [22], and eat more than their normal diet, as they have to gain sufficient weight for the long migratory journey [34,35]. This may lead to higher accumulation of metals in the blood, because they are processing higher quantities of horseshoe crab eggs than they normally would. This suggests that it would be interesting to examine the levels of metals in blood of a local resident shorebird or gull (e.g., laughing gull, Leucophaeus atricilla) that eats horseshoe crab eggs (but does not need to nearly double its weight in 2-3 weeks) during the spawning period, and again in the summer, when horseshoe crab eggs are no longer available.

Geographical data on horseshoe crab eggs from other places along the Atlantic coast indicate that arsenic levels are lower in Delaware Bay than most other places from Maine to Florida, while the levels of the other metals are similar among regions [44]. However, the levels of arsenic in horseshoe crab eggs from farther north are 2-3 times higher than those in Delaware Bay, indicating that exposure for shorebirds would be higher if they ate crab eggs farther north. Over time, arsenic has remained relatively constant in horseshoe crab eggs in Delaware Bay, while cadmium and mercury have declined, and chromium and lead showed no clear pattern [39].

Many species of shorebirds, including red knots, engage in multiday non-stop flights, consuming not only fat, but organ tissue as well. Thus, during the first two or three days at a stopover site, they consume eggs rapidly to rebuild their body systems. Thereafter, the eggs contribute to the fat build-up necessary for migration. Red knots, for example, need to almost double their weight to successfully migrate to their northern breeding grounds and arrive with sufficient resources to breed [35]. Ingested heavy metals are absorbed from the gastrointestinal tract into the circulating blood, and then distributed to other organs with eventual excretion or storage, including the feathers. In general, no prey source other than horseshoe crab eggs contributes significantly to the circulating 
levels of heavy metals. The metal levels in the eggs of horseshoe crabs clearly and dramatically declined between 1994 and 2012, and presumably the decline has continued [39]. However, there has not been a corresponding consistent decline in metal levels in the feathers of the same shorebirds. The declines varied by species [37]. This difference is due to the fact that feathers reflect circulating blood levels at the time of feather formation (43), and the feathers were formed in South America [5] prior to northbound migration. Thus, metals were sequestered in feathers while they were growing, when the birds were in South America. After feather formation is complete, there is no more blood supply to the feather. The three species do not winter in the same areas of South America, although there is some overlap. The levels of metals in blood when the shorebirds first arrive at Delaware Bay reflects mobilization from tissues during migration. If shorebirds lingered in Florida or farther south, blood levels would reflect levels in foods obtained at a more southern stopping area. For this reason, all blood was collected more than 4 days after the arrival of the shorebirds on Delaware Bay.

\subsection{Species Differences}

The levels of heavy metals in the blood of the three shorebirds showed similar patterns; levels reflected those in the eggs of horseshoe crabs (their prey). However, there were interspecific differences in arsenic for both blood and feathers, and for cadmium and chromium in blood. Semipalmated sandpipers had lower levels of arsenic in blood, and higher levels of arsenic in their feathers than the other species. The blood of shorebirds also had higher levels of arsenic than the other metals, which clearly reflects high levels in the eggs of horseshoe crabs [39]. Further, the blood levels of cadmium and chromium were higher in red knots than the other species. The reasons for these species differences are unclear, but might reflect initial differences when birds arrived at the bay, or food differences. Semipalmated sandpipers have a broader diet than other species, and consume marsh invertebrates as well as eggs [22,45], while the other species do not generally feed in marshes. Red knots had significantly higher levels of cadmium and chromium, which might reflect their complete reliance on horseshoe crab eggs, while sanderling sometimes feed along the Atlantic shore on invertebrates.

There were no interspecific differences in lead and mercury, two of the contaminants of main concern for species foraging in coastal and marine habitats. These two metals can cause a variety of adverse effects at higher levels (reviewed generally in Eisler [46,47] and Burger and Gochfeld [5]) and for these shorebirds, Tsipoura et al. [38]. Levels were generally below toxic effects level [38].

\subsection{Ratio of Metal Levels in Blood/Feathers for Shorebirds}

There are more studies of metal levels in feathers of birds than any other tissue, partly because heavy metals (e.g., mercury) concentrate in feathers, feathers are easy to collect non-destructively, can be stored easily, and the large number of studies with feathers allows comparisons among species and regions [3,48-50]. Feathers reflect blood levels of metals at the time they were grown [5]. Conversely, metals are not mobilized from feathers, so those metals do not contribute to toxicity. Thus, it is useful to know whether the same relationship exists between levels in feather and blood, because it indicates something about uptake of the metals in blood, and suggests whether the birds were coming from areas with the same contamination as obtained from Delaware Bay, or not. Arctic-breeding shorebirds usually grow their feathers on the wintering grounds or during northward migration [51,52]. Thus, because the three species examined spend the winter in different places (where the feathers were grown), it is not likely that the ratios would be the same among the three species. We found that ratios were inconsistent, reflecting the difference in diet during molt (in South America) vs while the shorebirds were in Delaware Bay.

\section{Conclusions}

All three species of shorebirds showed a similar, positive correlation of the levels of heavy metals in their blood with the levels of heavy metals in their primary prey (horseshoe crab eggs) while at the migratory stopover on Delaware Bay. The shorebirds had been in Delaware Bay more than 4 days, 
but less than 2 weeks, when blood was taken, indicating that within this time period, their blood levels reflect those in horseshoe crab eggs. This study provides clear evidence that levels of metals in the blood of shorebirds are closely correlated with those in their prey, and the relationship occurs rapidly (within days of arrival). Red knots had significantly higher levels of cadmium and chromium in their blood than the other species, reflecting their greater reliance on horseshoe crab eggs in their diet.

Acknowledgments: We thank Larry Niles and Amanda Dey for so ably leading the shorebird conservation program on Delaware Bay for over 20 years; Mark Peck and the Red Knot field team for logistical support; Albert Spry and the NJ Audubon field crew for help with sample collection; and Christian Jeitner for chemical and statistical analysis. Over the years, this project has been funded by NIEHS Center of Excellence (P30ES005022), Dupont's Clear into the Future Program, National Fish and Wildlife Foundation, Conserve Wildlife Foundation of New Jersey, and the Tiko Fund. We thank the Endangered and Nongame Species Program of NJ Department of Environmental Protection, and the U.S. Fish \& Wildlife Service for permits. The research was conducted under an approved protocol from Rutgers University (E97-017).

Author Contributions: All three authors conceived the project and designed the sampling. Joanna Burger and Nellie Tsipoura collected the samples. Joanna Burger oversaw the chemical analysis, and Michael Gochfeld oversaw the laboratory protocol and QA/QC for chemical and statistical analysis. Joanna Burger wrote the first draft, and all authors participated in ms review and editing of the $\mathrm{ms}$.

Conflicts of Interest: The authors declare no conflict of interest.

\section{References}

1. Nygard, T.; Lie, E.; Roy, N.; Steinnes, E. Metal dynamics in an Antarctic food chain. Mar. Pollut. Bull. 2001, 42, 598-602. [CrossRef]

2. Kim, J.; Koo, T.J. The use of feathers to monitor heavy metal contamination in herons, Korea. Arch. Environ. Contam. Toxicol. 2007, 53, 435-441. [CrossRef] [PubMed]

3. Burger, J.; Gochfeld, M. Habitat, Population Dynamics, and Metal Levels in Colonial Waterbirds: A Food Chain Approach; CRC Press: Boca Raton, FL, USA, 2016.

4. Furness, R.W.; Rainbow, P.S. Heavy Metals in the Marine Environment; CRC Press: Boca Raton, FL, USA, 1990.

5. Burger, J.; Gochfeld, M. Effects of chemicals and pollution on seabirds. In Biology of Marine Birds; Schreiber, B.A., Ed.; CRC Press: Boca Raton, FL, USA, 2001; pp. 485-576.

6. Fitzgerald, W.F.; Engstrom, D.R.; Lamborg, C.J.; Tseng, C.M.; Balcom, P.H.; Hamerschmidt, C.R. Modern and historic atmospheric mercury fluxes in northern Alaska: Global sources and Arctic depletion. Environ. Sci. Technol. 2005, 39, 557-568. [CrossRef] [PubMed]

7. Hammerschmidt, C.F.; Fitzgerald, W.F.; Lamborg, C.H.; Balcom, P.H.; Tseng, C.M. Biogeochemical cycling of methylmercury in lakes and tundra watersheds of Arctic Alaska. Environ. Technol. Sci. 2006, 40, 1204-1211. [CrossRef]

8. Burger, J. Shorebirds as marine animals. In Behavior of Marine Animals; Burger, J., Olla, E.J., Eds.; Plenum Press: New York, NY, USA, 1984; Volume 5, pp. 17-81.

9. Myers, J.P.; Morrison, R.I.G.; Antas, P.Z.; Harrington, B.A.; Lovejoy, T.E.; Sallaberry, M.; Senner, S.E.; Tarak, A. Conservation strategy for migratory species. Am. Sci. 1987, 75, 19-26.

10. Niles, L.J.; Sitters, H.P.; Dey, A.D.; Arce, N.; Atkinson, P.W.; Baker, A.J.; Bennett, K.A.; Buchanan, J.; Carmona, R.; Harrington, B.A.; et al. Status of the Red Knot, Calidris canutus rufa, in the Western Hemisphere. Stud. Avian Biol. 2008, 36, 1-185.

11. Niles, L.J.; Bart, J.; Sitters, H.P.; Dey, A.D.; Clark, K.E.; Aktinson, P.W.; Baker, A.J.; Bennett, K.A.; Kalasz, K.S.; Clark, N.A.; et al. Effects of horseshoe crab harvest in Delaware Bay on Red Knots: Are harvest restrictions working? BioScience 2009, 59, 153-164. [CrossRef]

12. Burger, J.; Niles, L.J.; Porter, R.; Dey, A.; Koch, S.; Gordon, D. Migration and overwintering of Red Knots (Calidris canutus rufa) along the Atlantic coast of the United States. Condor 2012, 114, 302-313.

13. Morrison, R.E.G.; Aubrey, Y.; Butler, R.W.; Beyersbergen, G.W.; Donaldson, G.M.; Gratto-Trevor, C.L.; Hicklin, P.W.; Johnson, V.H.; Ross, R.K. Declines in North American shorebird populations. Wader Study Group Bull. 2001, 94, 37-42.

14. Mizrahi, D.; Peters, K. Relationship between sandpipers and horseshoe crabs in Delaware Bay: A synthesis. In Biology and Conservation of Horseshoe Crabs; Tanacredi, J.T., Botton, M.L., Smith, D.R., Eds.; Springer: New York, NY, USA, 2009; pp. 65-88. 
15. Simmons, R.E.; Kolberg, H.; Brady, R.; Erni, B. Declines in migrant shorebird populations from a winter-quarter perspective. Conserv. Biol. 2015, 29, 877-887. [CrossRef] [PubMed]

16. Piersma, T.; Wiersma, P.; Gills, J. The many unknowns about plovers and sandpipers of the world: Introduction to a wealth of research opportunities highly relevant for shorebird conservation. Wader Study Group Bull. 1997, 82, 23-33.

17. Andres, B.A.; Smith, P.A.; Morrison, R.G.; Gratto-Trevor, E.L.; Brown, S.C.; Friis, C.A. Population estimates of North American shorebirds. Wader Study Group Bull. 2012, 119, 178-194.

18. Brown, S.; Gratto-trevor, C.; Porter, R.; Weiser, E.L.; Mizrahi, D.; Bentzen, R.; Boldenow, M.; Clay, R.; Freeman, S.; Girous, A.-A.; et al. Migratory connectivity of semipalmated sandpipers and implications for conservation. Condor 2017, 119, 207-224. [CrossRef]

19. Baker, A.J.; Gonzalex, P.; Morrison, R.I.G.; Harrington, B.A. Red Knot (Calidris canutus). In The Birds of North America; Poole, A., Ed.; Online Cornell Lab of Ornithology: Ithaca, NY, USA, 2013.

20. Western Hemisphere Shorebird Reserve Network (WHSRN) Western Hemisphere Shorebird Reserve Network List of Sites. Available online: http:/ / www.whsrn.org/sites/map-sites/sites-western-hemisphereshorebird-reserve-network (accessed on 23 August 2017).

21. Clark, K.E.; Niles, L.J.; Burger, J. Abundance and distribution of migrant shorebirds in Delaware Bay. Condor 1993, 95, 694-705. [CrossRef]

22. Tsipoura, N.; Burger, J. Shorebird diet during spring migration stop-over on Delaware Bay. Condor 1999, 101, 635-644. [CrossRef]

23. Brown, S.; Hickey, C.; Harrington, B.; Gill, R. United States Shorebird Conservation Plan; Manomet Center for Conservation Sciences: Manomet, MA, USA, 2001.

24. Walls, E.A.; Berkson, J.; Smith, S.A. The horseshoe crab, Limulus Polyphemus: 200 million years of existence, 100 years of study. Rev. Fish Sci. 2002, 10, 39-73. [CrossRef]

25. Shuster, C.N., Jr.; Botton, M.L. A contribution to the population biology of horseshoe crabs, Limulus polyphemus (L.), in Delaware Bay. Estuaries 1985, 8, 363-372. [CrossRef]

26. Botton, M.L.; Loveland, R.E.; Jacobsen, T.R. Site selection by migratory shorebirds in Delaware Bay, and its relationship to beach characteristics and abundance of horseshoe crab (Limulus polyphemus) eggs. Auk 1994, 111, 605-616.

27. Botton, M.L.; Loveland, R.E. Updating the life history of the Atlantic horseshoe crab, Limulus polyphemus. Jersey Shorel. 2001, 20, 6-9.

28. Dunne, P.; Sibley, D.; Sutton, C.; Wander, W. Aerial surveys in Delaware Bay: Confirming an enormous spring staging area for shorebirds. Wader Study Group Bull. 1982, 35, 32-33.

29. Burger, J.; Niles, L. Shorebirds, stakeholders, and competing claims to the beach and intertidal habitat in Delaware Bay, New Jersey, USA. Nat. Sci. 2017, 9, 181-205. [CrossRef]

30. Kraemer, G.; Michels, S. History of horseshoe crab harvest in Delaware Bay. In Biology and Conservation of Horseshoe Crabs; Tanacredi, J.T., Botton, M.L.A., Smith, D.R., Eds.; Springer: New York, NY, USA, 2009; pp. 299-313.

31. McGowan, C.P.; Hines, J.E.; Nichols, J.D.; Lyons, J.E.; Smith, J.E.; Smith, D.R.; Kalasz, K.S.; Niles, L.J.; Dey, A.D.; Clark, N.A.; et al. Demographic consequences of migratory stopover: Linking red knot survival to horseshoe crab spawning abundance. Ecosphere 2011, 2, 11-22. [CrossRef]

32. U.S. Fish \& Wildlife Service (USFWS). Migratory Bird Treaty Act Protected Species (10.13 Lists) as of December 2, 2017. USFWS. Available online: https:/ / www.fws.gov/birds/management/managed-species / migratory-bird-treaty-act-protected-species.php (accessed on 23 August 2017).

33. U.S. Fish \& Wildlife Service (USFWS). Programmatic Biological Assessment for Structural Shellfish Aquaculture Projects for Red Knot (Calidris canutus rufa); USFWS: Lower Delaware Bay, NJ, USA, 2016.

34. Baker, A.J.; Gonzalez, P.M.; Piersma, T.; Niles, L.J.; de Lima, I.; Nascimento, S.; Atkinson, P.W.; Collins, P.; Clark, N.A.; Minton, C.D.T.; et al. Rapid population decline in red knots: Fitness consequences of refuelling rates and late arrival in Delaware Bay. Proc. R. Soc. Lond. 2004, 271, 875-882. [CrossRef] [PubMed]

35. Morrison, R.I.G.; Davidson, N.C.; Wilson, J.R. Survival of the fattest body stores on migration and survival in Red Knot, Calidris canutus islandica. J. Avian Biol. 2007, 38, 479-487. [CrossRef]

36. Burger, J.; Gochfeld, M.; Niles, L.; Dey, A.; Jeitner, C.; Pittfield, T.; Tsipoura, N. Metals in tissues of migrant semipalmated sandpipers (Calidris pusilla) from Delaware Bay, New Jersey. Environ. Res. 2014, 133, 352-360. [CrossRef] [PubMed] 
37. Burger, J.; Tsipoura, N.; Niles, L.J.; Gochfeld, M.; Dey, A.; Mizrahi, D. Mercury, lead, cadmium, arsenic, chromium and selenium in feathers of shorebirds during migrating through Delaware Bay, New Jersey: Comparing the 1990s and 2011/2012. Toxics 2015, 3, 63-74. [CrossRef]

38. Tsipoura, N.; Burger, J.; Niles, L.; Dey, A.; Gochfeld, M.; Peck, M.; Mizrahi, D. Metal levels in shorebird feathers and blood during migration through Delaware Bay. Arch. Environ. Contam. Toxicol. 2017, 72, 562-574. [CrossRef] [PubMed]

39. Burger, J.; Tsipoura, N. Metals in horseshoe crab eggs from Delaware Bay, USA: Temporal patterns from 1993-2012. Environ. Monit. Assess. 2014, 186, 6947-6958. [CrossRef] [PubMed]

40. Wolfe, M.; Norman, D. Effects of waterborne mercury on terrestrial wildlife at Clear Lake: Evaluation and testing of a predictive model. Environ. Toxicol. Chem. 1998, 17, 214-227. [CrossRef]

41. SAS. Statistical Analysis System; SAS Institute: Cary, NC, USA, 2005.

42. Monteiro, L.R.; Furness, R.W. Seabirds as monitors of mercury in the marine environment. Water Air Soil Pollut. 1995, 80, 851-870. [CrossRef]

43. Evers, D.C.; Burgess, N.M.; Champous, L.; Hoskins, B.; Major, A.; Goodale, W.M.; Robert, J.T.; Poppenga, R.; Daigle, T. Patterns and interpretation of mercury exposure in freshwater avian communities in northeastern North America. Ecotoxicology 2005, 14, 193-221. [CrossRef]

44. Burger, J.; Dixon, C.; Shukla, T.; Tsipoura, N.; Gochfeld, M. Metal levels in horseshoe crabs (Limulus polyphemus) from Maine to Florida. Environ. Res. 2002, 90, 227-236. [CrossRef]

45. Mizrahi, D.S. Importance of soft-sediment habitat to migrating shorebirds staging in Delaware Bay during spring migration. In Final Report to National Fish and Wildlife Foundation; National Fish and Wildlife Foundation: Washington, DC, USA, 2013.

46. Eisler, R. Mercury hazards to fish, wildlife and invertebrates: A synoptic review. In U.S. Fish Wildlife Service Report 85; U.S. Department of the Interior, Fish and Wildlife Service: Washington, DC, USA, 1987.

47. Eisler, R. Lead hazards to fish, wildlife and invertebrates: A synoptic review. In U.S. Fish Wildlife Service Report 85; U.S. Department of the Interior, Fish and Wildlife Service: Washington, DC, USA, 1988.

48. Burger, J. Metals in avian feathers: Bioindicators of environmental pollution. Rev. Environ. Toxicol. 1993, 5, 197-306.

49. Furness, R.W.; Muirhead, S.J.; Woodburn, M. Using bird feathers to measure mercury in the environment: Relationship between mercury content and moult. Mar. Pollut. Bull. 1986, 17, 27-30. [CrossRef]

50. Frederick, P.C.; Hylton, B.; Health, J.A.; Spalding, M.G. A historical record of mercury contamination in Florida, USA as inferred from avian feather tissue. Environ. Toxicol. Chem. 2004, 23, 1474-1478. [CrossRef] [PubMed]

51. Atkinson, P.W.; Baker, A.J.; Bevan, R.M.; Clark, N.A.; Cole, K.B.; Gonzalez, P.M.; Newton, J.; Niles, L.J.; Robinson, R.A. Unravelling the migration and moult strategies of a long-distance migrant using stable isotopes: Red Knot Calidris canutus movement in the Americas. Ibis 2005, 147, 738-749. [CrossRef]

52. Lourenco, P.M.; Piersma, T. Migration distance and breeding latitude correlate with the scheduling of pre-alternate body moult: A comparison among migratory waders. J. Ornithol. 2015, 156, 657-665. [CrossRef]

(c) 2017 by the authors. Licensee MDPI, Basel, Switzerland. This article is an open access article distributed under the terms and conditions of the Creative Commons Attribution (CC BY) license (http:/ / creativecommons.org/licenses/by/4.0/). 